\title{
Aristotle on Self-Perception and Pleasure
}

\author{
Manuel C. Ortiz de Landázuri
}

In this paper I examine the connection which Aristotle establishes between pleasure and activity, and more precisely, between pleasure and self-perception. I defend that when Aristotle links pleasure with activity he is referring to the conscious activities of the soul: seeing, knowing, feeling good, etc. Pleasure occurs in our consciousness of perfection because we experience pleasure when we feel that our nature develops in the right way. Pleasure is not something extra to the activity, but a self-perception of the good development of conscious activity, and this way of understanding pleasure helps to solve some questions raised of interpretation by J. O. Urmson and D. Frede.

Aristotle links pleasure with activity in his treatment of pleasure in books VII and $\mathrm{X}$ of the Nicomachean Ethics. Scholars have usually discussed whether pleasure is something that accompanies activity or something peculiar to the activity itself ${ }^{1}$. As Owen points out, in the seventh book Aristotle identifies pleasure with the pleasurable activities, while in the tenth book treats pleasure as something that accompanies them ${ }^{2}$.

\footnotetext{
${ }^{1}$ The main problem is that pleasure seems to be part of the activity, something necessary for the subjective perfection, but at the same time is like a result or effect of the activity. «Gewiss kann

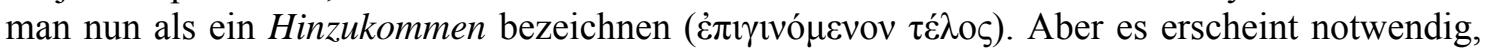
darauf aufmerksam zu machen, dass Aristoteles nicht sagt: die Lust ist ein $\pi \rho 0 \sigma \gamma \varepsilon v o ́ \mu \varepsilon v o v$ (so wie Platon sich immer ausdrückt: etwas ist dann schön, wenn die Idee des Schönen $\pi \rho \circ \sigma \gamma(\gamma v \varepsilon \tau \alpha l)$ oder sie ist ein $\pi \rho 0 \sigma \tau \imath \theta \varepsilon ́ \mu \varepsilon v o v$. Davon würde gelten, was 1172 b 23-32 gesagt ist.

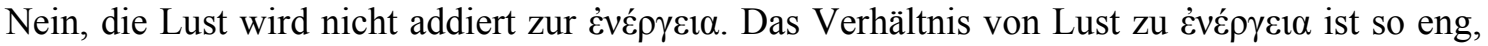
dass man sogar zweifeln kann ob sie nicht identisch sind (1175 b 33). Der Vorgang ist komplizierter, innerlicher». Dirlmeier, Franz, Aristoteles: Nikomachische Ethik (Akademie Verlag 1999), p. 582.

${ }^{2}$ Cfr. Owen, G. E. L. "Aristotelian Pleasures", Logic, Science and Dialectic, G. E. L. Owen and M. Nussbaum (eds.), (Cornell University Press 1986), p. 336.
} 
Journal of Ancient Philosophy Vol. VI 2012 Issue 2

What it seems interesting is the sense in which Aristotle talks about activity in the tenth book of the Nicomachean Ethics. In this paper I will try to show that when it is said that pleasure accompanies activity, he is referring in an implicit way to conscious acts, such as feeling, seeing, touching, feeling, thinking or knowing, and that pleasure is a selfperception of the good development of conscious activity. For this task, I will try to establish a connection between the treatment of pleasure of the tenth book and his philosophy of life and soul, especially of the De Anima. Finally, I will try to solve some questions of interpretation raised by J. O. Urmson and D. Frede.

$$
-\mathrm{I}-
$$

The relation between pleasure and self-perception is not explicit in the Nicomachean Ethics, and it needs some explanation. There are two main uses of the word «pleasure» in ordinary language. «Pleasure» can refer to the pleasurable activity, as when someone says that "playing football is a pleasure», or it can refer to the pleasure which occurs when that activity is done with perfection, as when someone says that «playing football brings me pleasure». The first use doesn't make a distinction between the pleasurable activity and the pleasure it brings. In the seventh book of the Nicomachean Ethics Aristotle seems to be treating pleasure in this first sense, identifying pleasure with the unimpeded activity of the natural state ${ }^{3}$. In the tenth book, Aristotle asks about the nature of pleasure, and treats it as something that accompanies activity: «Pleasure completes the activity (not as the corresponding permanent state does, by its immanence, but as an end which supervenes as the bloom of youth does on those in the flower of their age» ${ }^{4}$. There are two different doctrines of pleasure, and it is necessary to ask if it is possible to have an accordance between both treatises. In an implicit way Aristotle is answering different questions in each treatise: in book VII, Aristotle shows the conditions of possibility of pleasure: the requirements which are

\footnotetext{
${ }^{3}$ Cfr. Ethica Nicomachea, 1153 a 13-16.

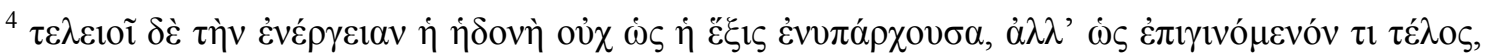

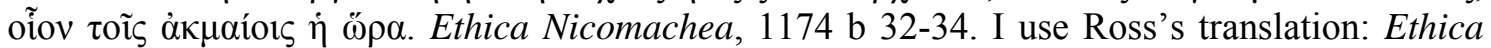
Nicomachea (Oxford 1915).
} 
needed so that an activity is pleasurable. That is, the perfect development of our nature. In book X, he is asking about the nature of pleasure, and how can this be related to the good life and virtue ${ }^{5}$. So both doctrines, far from being in disagreement, are compatible, and it seems that Aristotle treats pleasure with different points of view ${ }^{6}$.

According with what is said in book VII of the Nicomachean Ethics, we may notice that pleasure only occurs when a natural activity is performed in a perfect way: «It is not right to say that pleasure is a perceptible process, but it should rather be called activity of the natural state, and instead of 'perceptible' 'unimpeded'» ${ }^{7}$. Each living being has its own natural dispositions, from which spring natural activities. Some of these activities are done in order to preserve life (nourishing, reproduction), but others have their end in themselves (to perceive, to think, etc.), so they are sought because they make life better. This is why Aristotle distinguishes between two kinds of pleasure: «By things pleasant incidentally I mean those that act as cures (for because as a result people are cured, through some action of the part that remains healthy, for this reason the process is thought pleasant); by things naturally pleasant I mean those that stimulate the action of the healthy nature» ${ }^{8}$. There is pleasure when the natural faculties develop in the right way: because they are being healed or because they perform their activities properly. Pleasure only happens when the natural powers of a living being reach their perfection, and this is the objective aspect of pleasure: the perfection of natural activity.

\footnotetext{
${ }^{5}$ This is Festugière's opinion: «Selon (A), le plaisir est donc l'exercise parfait de la vertu. Selon (B), il est ce qui parfait cet exercice. La différence est réelle, mais elle implique une précision de la doctrine, non pas une contradiction. Dans le premier traité, opposant le plaisir à la $\gamma \varepsilon ́ v \varepsilon \sigma 1 \zeta$, Aristote, qui n'est pas encore maître absolu de ses concepts, conclut simplement que le plaisir est activité. Une réflexion plus pausée lui fait reconnaître que le plaisir n'est pas, au sens propre, activité, mais qu'il jaillit de l'activité parfaite come le signe de cette perfection, ainsi que la santé parfaite, à la fleur de l'âge, s'épanouit en beauté». Festugière, André-Jean, Aristote. Le plaisir. Introduction, traduction et notes (Vrin 1946), p. XXIV.

${ }^{6}$ Cfr. Owen, G. E. L. "Aristotelian Pleasures", Logic, Science and Dialectic, G. E. L. Owen and M. Nussbaum (eds.), (Cornell University Press 1986), p. 335.

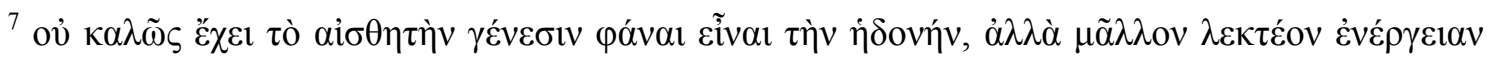

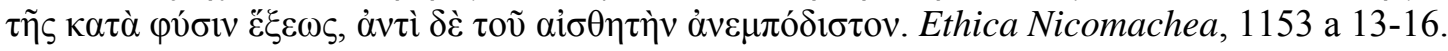

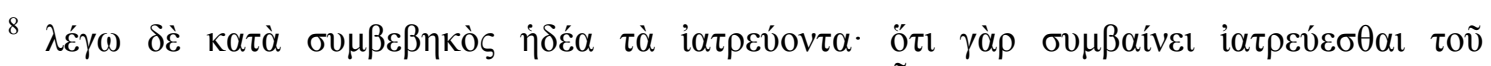

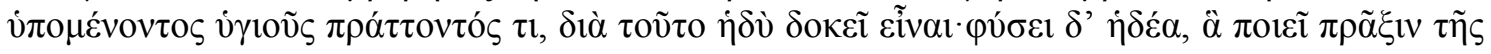

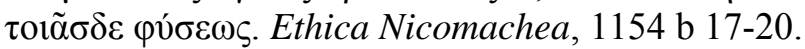


But, on the other hand, there is another condition required in order to feel pleasure: we must experience that our natural powers come into perfection, which is to say that some kind of consciousness or awareness must be present when the natural activity reaches perfection ${ }^{9}$. Animals differ from plants in that they have sensations and awareness, they can feel if their own life and activities are in a good or bad state, and so, their activities are accompanied by pleasure and pain: «where there is sensation, there is also pleasure and pain, and, where these, necessarily also desire» ${ }^{10}$. Plants, on the contrary, develop their natural capacities without feeling them, and they do not experience pleasure or pain $^{11}$. Thus, here is the subjective aspect of pleasure: the consciousness or awareness by which the activity is felt, and it is in this consciousness where pleasure occurs.

In this sense, there is an interesting text in the IX book of the Nicomachean Ethics in which Aristotle links the act of perceiving that we perceive with pleasure: «That which is good by nature, we have said, is for the virtuous man good and pleasant in itself. Now life is defined in the case of animals by the power of perception, in that of man by the power of perception or thought; and a power is defined by reference to the corresponding activity, which is the essential thing; therefore life seems to be essentially the act of perceiving or thinking. And life is among the things that are good and pleasant in themselves, since it is determinate and the determinate is of the nature of the good [...]. But if life itself is good and pleasant [...], and if he who sees perceives that he sees, and he who hears, that he hears, and he who walks, that he walks, and in the case of all other activities similarly there is something which perceives that we are active, so that if we perceive, we perceive that we perceive, and if we think, that we think; and if to perceive that we perceive or think is to perceive that we exist (for existence was

\footnotetext{
${ }^{9}$ «Perceptions and thoughts do not give rise to pleasure as sources to some ethereal subject languishing behind acts of perception and thought. Rather, perceptions and thoughts are pleasures; they are pleasures when our faculties are functioning well and ranging over fine objects». Shields, Christopher, "Perfecting Pleasures: The Metaphysics of Pleasure in Nicomachean Ethics X", Aristotle's Nicomachean Ethics. A Critical Guide, J. Miller (ed.) (Cambridge University Press 2011), p. 210.

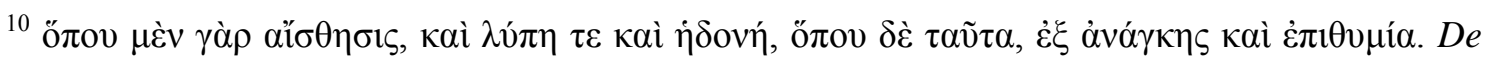
Anima, 413 b 22-23. I use E. S. Forster's translation (ed. Ross): De Anima (Oxford 1963).

${ }^{11}$ This is because plants lack a mésotes. Living beings perceive from a medium, or specific term.
} 
Journal of Ancient Philosophy Vol. VI 2012 Issue 2

defined as perceiving or thinking); and if perceiving that one lives is in itself one of the things that are pleasant (for life is by nature good, and to perceive what is good present in oneself is pleasant); and if life is desirable, and particularly so for good men, because to them existence is good and pleasant (for they are pleased at the consciousness of the presence in them of what is in itself good); and if as the virtuous man is to himself, he is to his friend also (for his friend is another self): -if all this be true, as his own being is desirable for each man, so, or almost so, is that of his friend» ${ }^{12}$.

Pleasure has to do with the perception of good existence, with the awareness that our vital powers come to fulfilment, and in this sense can Aristotle say that the good man is pleased with his own life and existence and, therefore, with the consciousness of perfection of his friend. This conception of pleasure shows a link between our perception (not only of the world, but primarily of ourselves) and the pleasure or pain we experience. So it seems that when Aristotle says that pleasure accompanies activity, he is referring to the human (or animal) activity as a whole, with the perception that feels the activity reaching its end ${ }^{13}$. Modern philosophers such as Descartes and Locke have understood knowledge as an activity by which the human being gets to know the world in an objective way. Reception of objective data has been, since then, the

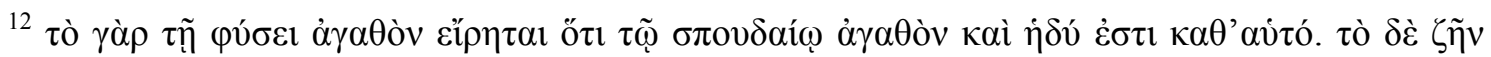

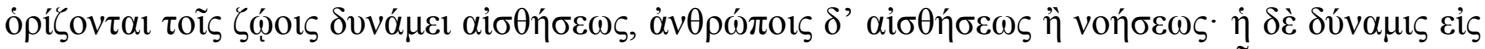

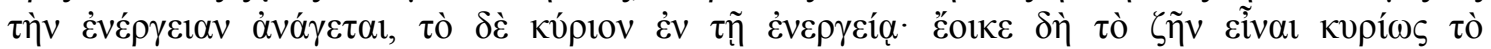

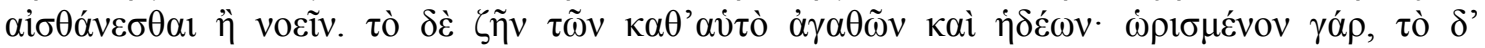

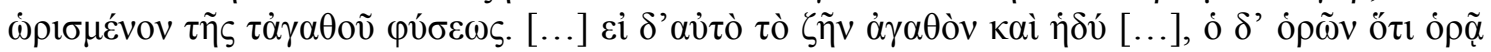

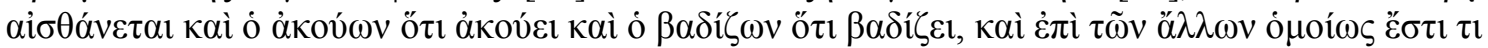

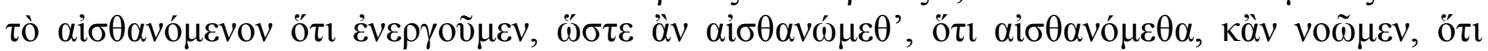

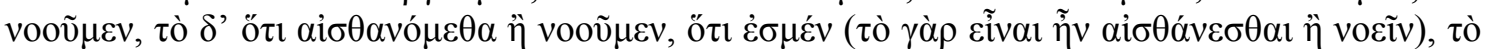

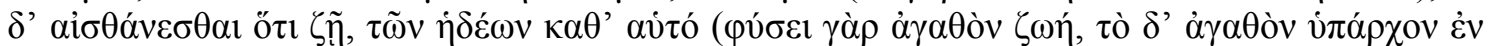

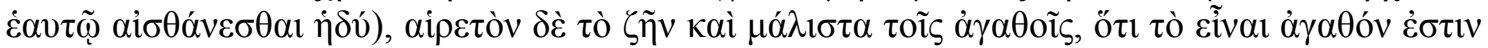

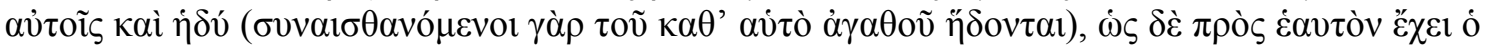

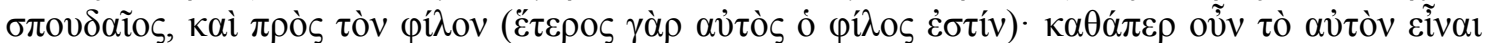

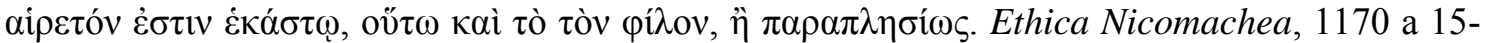
1170 b 8.

${ }^{13}$ As Joachim noticed: «Aristotle's position would seem to carry with it logically that to regard activity as complete apart from feeling is an unreal abstraction. All human activity involves feeling -pleasure or pain- and if the feeling of pleasure perfects the activity, will not the absence of pleasure diminish the perfection of the activity?». Joachim, Harold H., Aristotle. The Nicomachean Ethics (Greenwood Press 1985), pp. 283-4.
} 
common treatment of knowledge. The Aristotelian treatment of pleasure gives light to understand knowledge and the conscious activity not only from an objective point of view, but also from the subjective one. Pleasure and pain accompany each activity when they are felt as good or bad. This is clear in the case of sensibility: «To feel pleasure or pain is to act with the sensitive mean towards what is good or bad as such» ${ }^{14}$. The act of the sensibility involves the pleasure or pain we experience. But, what does exactly mean «to feel pleasure or pain»? It is something so simple as to feel good or bad, in relation with something we perceive, think or experience. Once we perceive or think something, we have an internal experience in relation with that which is perceived or thought. These experiences, which we call pleasure or pain, are also a sensitive evaluation of what happens to us. Conscious activities have an objective aspect (what it is seen, what we have done, what we get to know, etc.) and a subjective one (how do we feel with respect to the objective aspect) ${ }^{15}$. Aristotle associates perception with some kind of awareness, because when a human being feels of thinks, he 'notices what is going on ${ }^{16}$, and he feels his own being through pleasure or pain in relation to 'what is going on, 17 .

Having stated that pleasure is related with the self-perception, it seems interesting

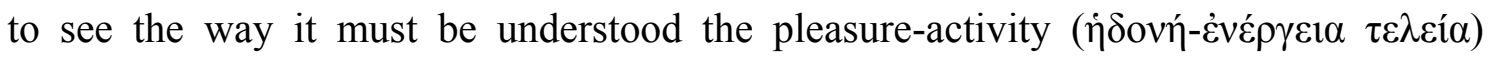
scheme of the tenth book of the Nicomachean Ethics. In the tenth book Aristotle

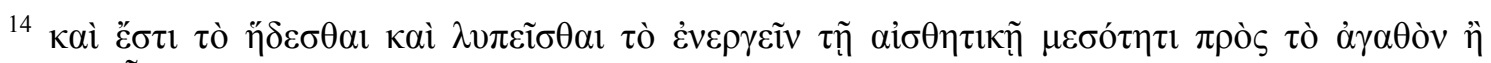

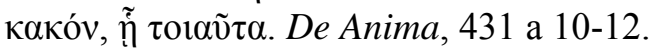

${ }^{15}$ Charles Kahn has tried to show that Aristotle's concept of sensation implies pleasure and pain, some kind of self-consciousness: «Thus, although (and particularly in the De Anima) he tends to restrict $\alpha$ ilo $\theta \eta \sigma ı \varsigma$ to objective perception via the external senses, and avoids using the term for 'subjective' experience such as pleasure and pain, he everywhere insists upon the close

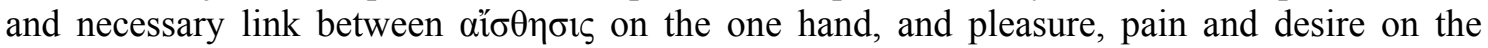
other». Kahn, Charles H., "Sensation and Consciousness in Aristotle's Psychology", Archiv für Geschichte der Philosophie 48 (1966), p. 72.

16 «The inanimate is unconscious of being affected by alteration, whereas the animate is conscious (ở $\lambda \alpha v \theta \alpha ́ v \varepsilon \imath)$ of it». Physics, 245 a 1.

${ }^{17}$ «Where there is sensation, there is also pleasure and pain, and, where these, necessarily also desire». De Anima, 413 b 22-23. 
Journal of Ancient Philosophy Vol. VI 2012 Issue 2

compares pleasure with the act of vision: «Seeing seems to be at any moment complete, for it does not lack anything which coming into being later will complete its form; and pleasure also seems to be of this nature. For it is a whole, and at no time can one find a pleasure whose form will be completed if the pleasure lasts longer. For this reason, too, it is not a movement» ${ }^{18}$. Pleasure is something perfect at any time in which it occurs. You can feel or not feel pleasure, but what is impossible is to quasi-feel it. This is a peculiarity of all conscious acts, and in this way pleasure is related with the $\dot{\varepsilon} v \varepsilon \dot{\varepsilon} \rho \gamma \varepsilon 1 \alpha$.

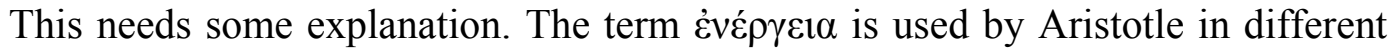
contexts, with different connotations ${ }^{19}$. In a general way, $\dot{\varepsilon} v \varepsilon \dot{\varepsilon} \rho \varepsilon 1 \alpha$ is characterized as

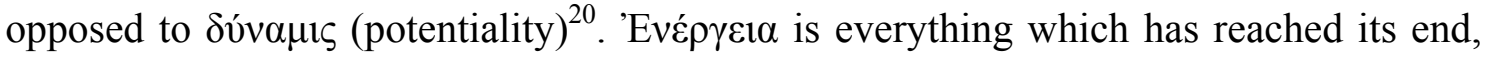

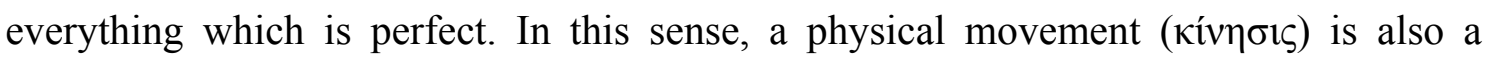

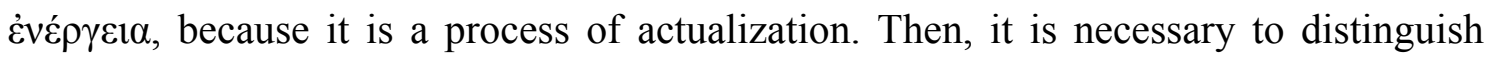

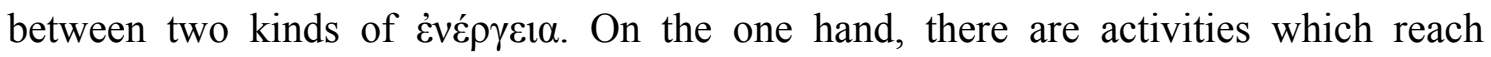
perfection only when the activity has ended: for example, the activity of building a house. The end of the activity, the house, is achieved only when we have stopped building. This kind of activities, which are processes, are called by Aristotle in the

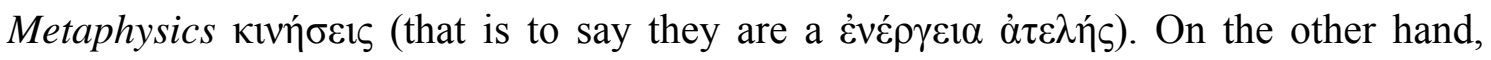
there are activities in which their end is in the activity itself: for example seeing. Once I see, I have the object seen, and I continue seeing. The act of seeing is complete at any

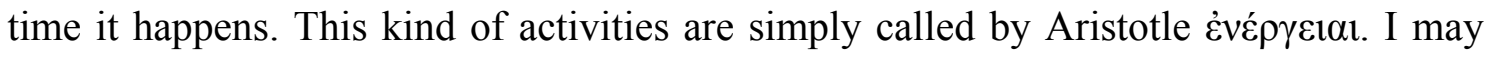

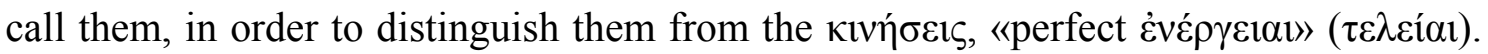
This distinction, which is not explicit in the tenth book of the Nicomachean Ethics, gives light to understand the nature of pleasure as something which accompanies or

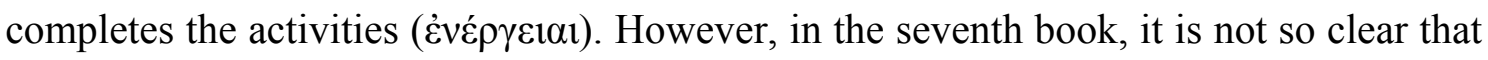

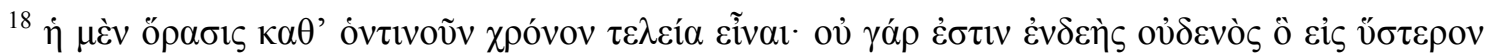

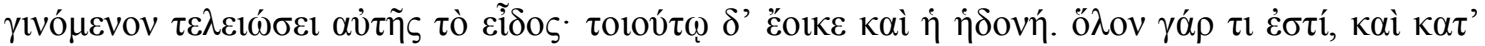

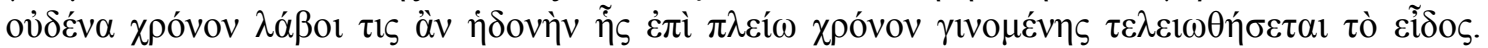

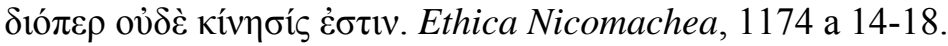

19 Cfr. Chung Hwang, "Different Meanings of the Term Energeia in the Philosophy of Aristotle", Philosophy and Phenomenological Research 17 (1956), pp. 56-65.

${ }^{20}$ Cfr. Bonitz, Hermann, Aristotelis Opera (vol. V). Index Aristotelicus (Walter de Gruyter \& Co. 1961), p. 251.
} 
Journal of Ancient Philosophy Vol. VI 2012 Issue 2

Aristotle could have this distinction in mind: although he denies that pleasure is a process $(\gamma \varepsilon \dot{\varepsilon} \varepsilon \sigma 1 \zeta)$, there are no indications to consider that he viewed pleasure as an $\dot{\varepsilon} v \varepsilon \dot{\varepsilon} \rho \gamma \varepsilon 1 \alpha$ of the perfect type (or something related to a perfect $\dot{\varepsilon} v \varepsilon \dot{\varepsilon} \rho \gamma \varepsilon 1 \alpha$ ), because he simply identifies pleasure with the unimpeded activity ${ }^{21}$.

In the tenth book Aristotle compares pleasure with the act of vision because

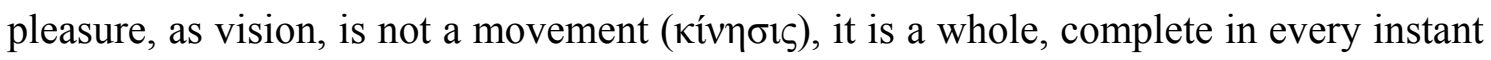
in which happens. That is the same as to say that pleasure is a $\dot{\varepsilon} v \varepsilon \dot{\varepsilon} \rho \gamma \varepsilon 1 \alpha$ of the perfect type, although Aristotle does not say it explicitly anywhere. But there are references which justify that he viewed pleasure as a perfect $\dot{\varepsilon} v \varepsilon \dot{\rho} \gamma \varepsilon 1 \alpha$. In Metaphysics $\Lambda$ he assimilates God's activity with pleasure: «Its actuality is also pleasure» ${ }^{22}$, and it is clear

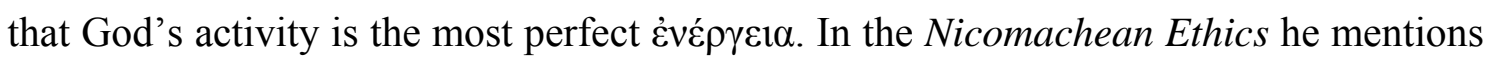

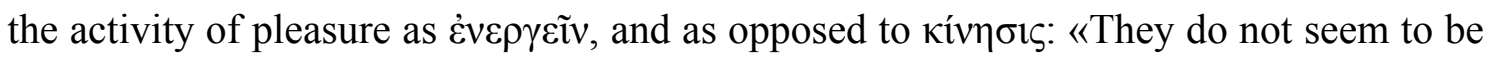
right even in saying that it is a movement. For speed and slowness are thought to be proper to every movement, and if a movement, e.g. that of the heavens, has not speed or slowness in itself, it has it in relation to something else; but of pleasure neither of these things is true. For while we may become pleased quickly as we may become angry quickly, we cannot be pleased quickly, not even in relation to some one else, while we can walk, or grow, or the like, quickly. While, then, we can change quickly or slowly

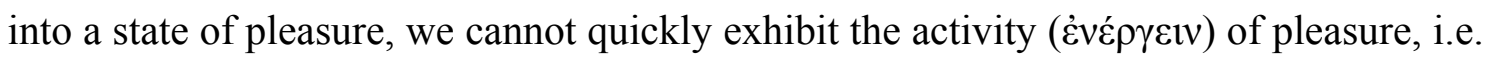
be pleased $»^{23}$.

\footnotetext{
${ }^{21}$ «In book VII pleasure is identified with $\dot{\varepsilon} v \varepsilon \dot{\varepsilon} \gamma \varepsilon \varepsilon 1 \alpha$ only because it is not a $\gamma \varepsilon \dot{\varepsilon} \varepsilon \sigma ı \varsigma$. No further reason is given for identifying the two nor is it explicitly claimed that they are in every way identical. One can claim that a horse is an animal while not thereby implying that there is no difference between being a horse and being an animal. Such identity claims are ambiguous and must be understood from their context. In book VII that context is an argument that pleasure is not a becoming or process. Since in Aristotle's thought the fundamental opposition in speaking

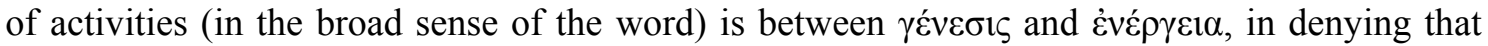
pleasure is the former he is naturally led to identify it with the latter. Such an identification, however, does not exclude the possibility that upon further examination there may be seen to be some kind of distinction between the two». González, Francisco J., "Aristotle on Pleasure and Perfection", Phronesis 36 (1991), p. 147.

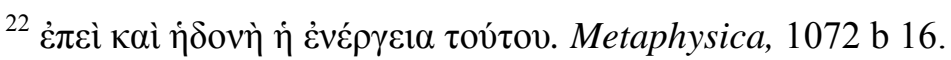

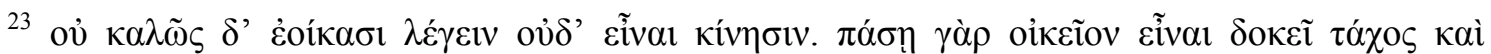

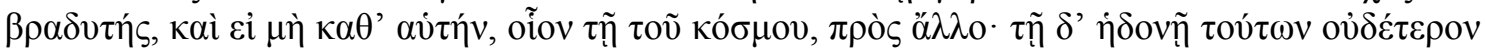


Journal of Ancient Philosophy Vol. VI 2012 Issue 2

However, there is a problem of difficult solution. Having stated that pleasure shares the characteristics of the perfect activity ( $\dot{\varepsilon} \vee \varepsilon \gamma \varepsilon \varepsilon \alpha)$, which is the proper relation with it? Is pleasure a $\dot{\varepsilon} \varepsilon \dot{\rho} \gamma \varepsilon \varepsilon \alpha$, or something which is superadded to it? On the one hand, Aristotle affirms that pleasure shares the same characteristic with the conscious activity: it is perfect at any time. On the other hand, Aristotle nowhere in the tenth book says that pleasure is an activity in itself, but something that accompanies them ${ }^{24}$. The

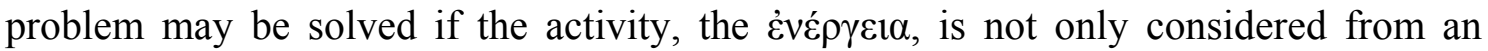
objective point of view, but also from the subjective. An activity is not only that which

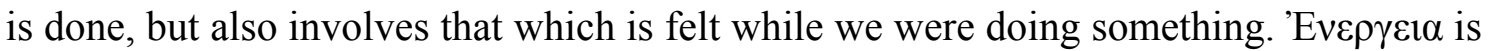
the human action as a whole: the activity, not only from the outside (what is done), but also from the inside (how it is felt). The conclusion is that pleasure is a feeling of the

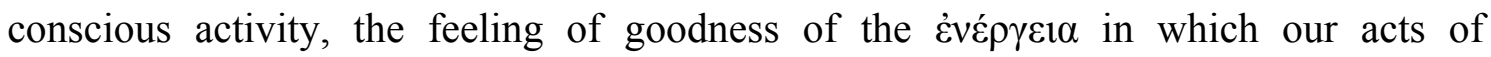
perception, sensation and knowledge consist. That is the same as to say that it is a

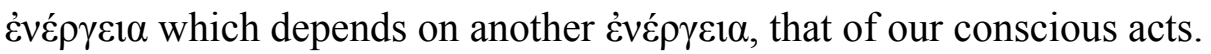

The view that pleasure is a feeling of self-perception in the conscious activities (so that always accompanies a $\dot{\varepsilon} v \varepsilon \dot{\varepsilon} \gamma \varepsilon 1 \alpha$ ) does not contradict the fact that pleasure can

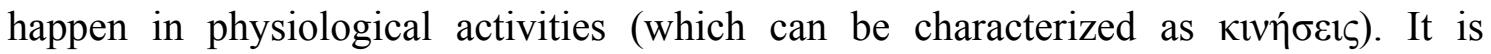
important to notice that those processes, such as eating, drinking, running or having sex, are pleasurable because there is some kind of perception in them (and this perception is a perfect $\dot{\varepsilon} v \varepsilon \dot{\rho} \gamma \varepsilon 1 \alpha)$. That is the reason why humans and animals have pleasure in the good development of their natural activities while plants not. Plants lack a $\mu \varepsilon \sigma o ́ \tau \eta \varsigma$, they don't have a medium from where to perceive. Pleasure happens when a natural capacity has reached its end, and that perfection is perceived ${ }^{25}$.

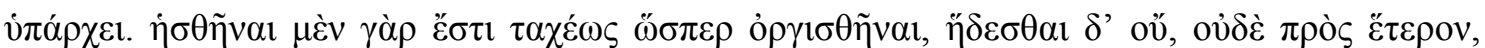

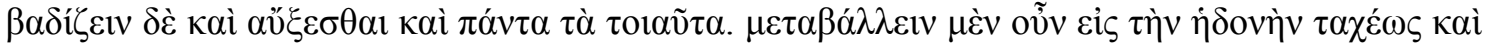

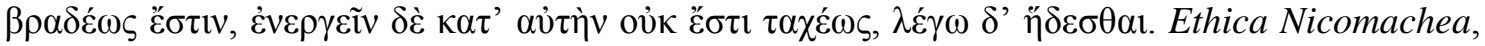
1173 a $31-1173$ b 4.

${ }^{24}$ See Ricken, Friedo, "Wert und Wesen der Lust", Aristoteles. Die Nikomachische Ethik, O. Höffe (ed.), (Akademie Verlag 1995), p. 221.

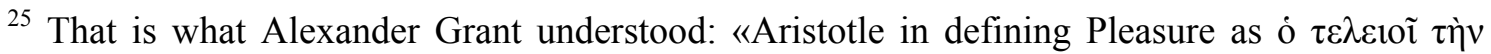

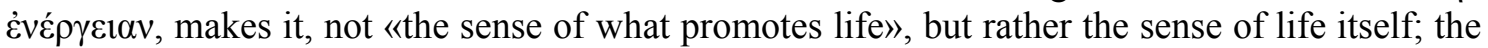
sense of the vividness of the vital powers; the sense that any faculty whatsoever has met its 
Journal of Ancient Philosophy Vol. VI 2012 Issue 2

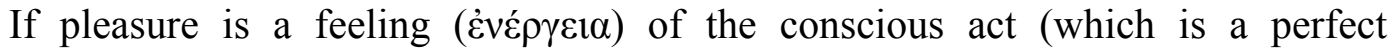
$\dot{\varepsilon} v \varepsilon \dot{\varepsilon} \gamma \varepsilon \varepsilon \alpha$ ), there is no problem for the application of the pleasure-activity scheme to the «replenishment processes». In these kind of activities there is a remedy of a lack for the

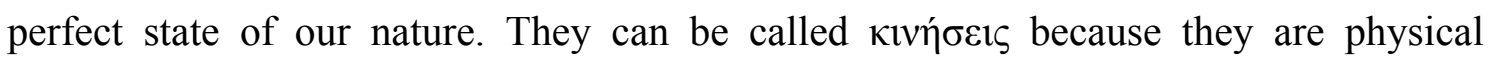
movements which require time to reach perfection. But, on the other hand, these processes are pleasurable when they are felt, when we are conscious of them, and that is

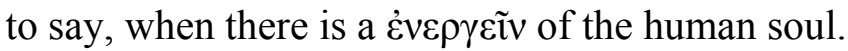

The metaphysical account of pleasure of the tenth book of the Nicomachean

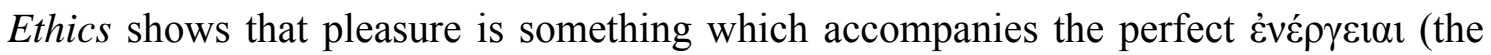
conscious activities: thinking, knowing, perceiving), making them better from the inside. Pleasure is a self-perception or feeling ( $\dot{\varepsilon} \vee \varepsilon \gamma(\gamma \varepsilon \alpha)$ of the right development of conscious living.

This conception of pleasure as the consciousness of the perfect development of one's own life can be contrasted with Urmson's and Frede's interpretation of Aristotle's treatment of pleasure. Urmson thinks that Aristotle understands pleasure in the tenth book of the Nicomachean Ethics as perfect activity and that he tries to apply this concept to all kinds of pleasure, when there are pleasures which cannot be treated in this way. In his opinion, there are two kinds of pleasures: the enjoyment of activities (in which the pleasure-activity treatment fits properly), and the pleasant feelings which are a product of things we do, but not an enjoyment of the activity itself (and, in this case, the pleasure-activity treatment would not be valid). These pleasant feelings would be

proper object. This definition then is equally applicable to the highest functions of the mind, as well as to the bodily organs. Even in the case of pleasure felt upon the supplying of a want, the Aristotelian doctrine with regard to that pleasure was, that it was not identical with the supply, but contemporaneous; that it resulted from the play and action of vital powers not in a state of depression, while the depressed organs were receiving sustenance. [...] Pleasure then, according to Aristotle, proceeds rather from within than from without; it is the sense of existence; and it is so inseparably connected with the idea of life, that we cannot tell whether life is desired for the sake of pleasure, or pleasure for the sake of life». Grant, Alexander, The Ethics of Aristotle, illustrated with essays and notes (Longmans 1874), vol. I, pp. 248-9. 
those involved in the intemperate activities, linked with the sense of touch, according with a distinction that makes Aristotle in the III book of the Nicomachean Ethics: «Temperance and self-indulgence, however, are concerned with the kind of pleasures that the other animals share in, which therefore appear slavish and brutish; these are touch and taste» ${ }^{26}$. In this way, Urmson says that «Aristotle fails to make explicitly clear to himself the central point; he persuades himself that the intemperate pleasures are to be distinguished from the pleasure of looking at pictures because they involve the sense of touch and thus fails to see that he has really made a distinction between enjoying activities essentially involving use of the senses and doing things which produce a pleasant feeling ${ }^{27} »$. And so, Aristotle «makes the uncommon error of assimilating the enjoyment of feelings to the enjoyment of activity ${ }^{28} »$. Urmson's position about the Aristotelian doctrine of pleasure emphasizes the differences between pleasures, but it

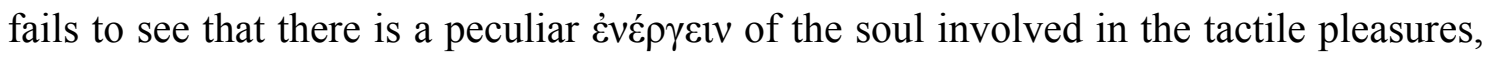
and that even these «pleasurable sensations» are some kind of $\dot{\varepsilon} v \varepsilon \dot{\rho} \gamma \varepsilon 1 \alpha$, the perfect use of our senses. That is exactly what C. C. W. Taylor has replied: "While Aristotle believes that the intemperate man goes for his intemperate activities for the sake of bodily sensations, he does not say or imply that he enjoys only those sensations and not the activities themselves. Intemperate pleasures are important examples of a sort of enjoyment of activity that is itself constituted in part by the enjoyment of sensations. Hence in those cases it is a mistake to infer that someone who enjoys that sort of sensation does not enjoy the activities themselves. But that mistake, if committed by anyone, has been committed by Urmson, not by Aristotle. Where Aristotle goes wrong is in his very queer view of what it is that is enjoyable about «intemperate» activities [...]. Specifically, he is wrong to classify all these forms of enjoyment as consisting purely in the enjoyment of tactile sensations. But, contra Urmson, he is right to think

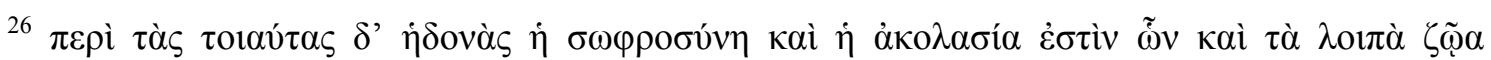

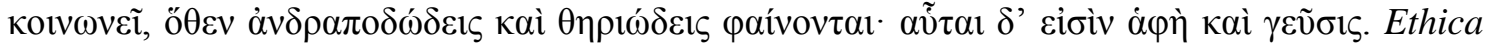
Nicomachea, 1118 a 23-26.

${ }^{27}$ Urmson, James O., “Aristotle on Pleasure”, Aristotle: a Collection of Critical Essays, J. M. E. Moravcsik (ed.) (Macmillan 1968), p. 329.

${ }^{28}$ Urmson, James O., “Aristotle on Pleasure”, p. 331.
} 
Journal of Ancient Philosophy Vol. VI 2012 Issue 2

that the enjoyment of tactile sensations fits happily into his general account of pleasures as the enjoyment of activities, under the heading of enjoyment of the exercise of the senses» ${ }^{29}$.

In this way it is interesting the position of David Bostock, who explains that the enjoyment is not the replenishment, but the awareness or perception of this replenishment: «The pleasure cannot just be the replenishment, for the replenishment takes place in the body, whereas we do not say that it is the body that is pleased (1173b9-11). The pleasure, then, does not take place in the body. So where does it take place? The obvious answer is 'in the mind'. And what is it that goes on in the mind when one's body is replenished, and one is pleased by this? Evidently, the perception of this replenishment. In the standard case, my perceiving faculties will not be at all impaired, and I can taste, touch, and feel perfectly well when I am thirsty. So the thought is that what I enjoy is not, as we loosely say, the drinking, but rather the taste of the drink, its cooling touch in my throat as it goes down, and very possibly the bodily feeling that I have, which can only be described as feeling that the drink is doing me good, as my thirst disappears. These are perceptions, and perception is certainly something that Aristotle counts as an activity, of the kind that can be (or be 'completed' by) a pleasure, whereas the drinking itself is a process. My suggestion is, then, that in a so-called 'pleasure of replenishment' Aristotle's view is that the pleasure is to be found not in the replenishment itself but in the perception of it. It is this perception that is the associated activity of an unimpaired part of us» ${ }^{30}$. In this way, pleasure accompanies a perfect activity of perception, which in case of the replenishment processes is a perception or awareness of this replenishment, and this activity is perfect because its object, the replenishment, is perfect. So the pleasure-activity explanation of pleasure of the tenth book fits can be applied also to this kind of pleasurable activities.

In some way, as a continuation of Urmson's position, we have the interpretation of Aristotle's doctrine on pleasure made by Dorothea Frede. Frede thinks that there are

\footnotetext{
${ }^{29}$ Taylor, C. C. W., "Urmson on Aristotle on Pleasure", Pleasure, Mind and Soul, C. C: W. Taylor (ed.) (Clarendon Press 2008), p. 119.

${ }^{30}$ Bostock, David, "Pleasure and Activity in Aristotle's Ethics”, Phronesis 33 (1988), p. 269.
} 
Journal of Ancient Philosophy Vol. VI 2012 Issue 2

two kinds of pleasures: the pleasure which accompanies the perfect activities (such as hearing, knowing, seeing, etc.), that Aristotle treats in books VII and X of the Nicomachean Ethics, and pleasures which appear as an effect of the fulfilment of a desire (such as eating, drinking, etc.), which are treated in the Rhetoric as a process of restoration to the natural state. For Frede, Aristotle is not aware that this distinction exists, even though we find a different treatment in the Nicomachean Ethics and in the Rhetoric: «Did he realize that neither «pleasure» nor «pain» constitutes a unitary genus and therefore any attempt to give a unified definition of its nature must fail? Aristotle is not usually shy to admit a plurality of meanings for key terms. So why did he not come up with the solution he resorts to in other connections, namely that 'pleasure is used in many ways', with his favourite type of pleasure as the 'focal meaning' of the other, secondary kinds? In the case of pleasure, such a solution would be highly problematic: it would presuppose that all pleasures relate to the central type in the way that all healthy things depend on health as their focus [...]. No such relation seems to exist between pleasure as an integral part of a perfect activity and the other kinds that consist in the fulfilment of a desire, in the restoration of a mental (or physical) equilibrium, or in the sheer 'feel' of sensuous pleasures ${ }^{31}$ ».

Although it is true that Aristotle doesn't have the same concept of pleasure in all his writings, the question is whether Aristotle's treatment of pleasure in the Nicomachean Ethics (particularly in the tenth book) is suitable for explaining the metaphysical and psychological status of pleasure in all cases and experiences. Aristotle links pleasure with the perfect $\dot{\varepsilon} v \varepsilon \dot{\varepsilon} \rho \gamma \varepsilon 1 \alpha$, with the activities of knowledge and sensation, and, as it has been shown, with some kind of awareness or feeling (that is why animals feel pleasure but plants do not). This pleasure-scheme seems to explain also the pleasure of restorative activities, because these processes are pleasurable in the way they are felt. The pleasures which accompany the satisfaction of a desire are due to the awareness of a perfection of the natural state. For example, when someone is thirsty and drinks some water, he feels pleasure because there is something which satisfies the faculty of

\footnotetext{
${ }^{31}$ Frede, Dorothea, "Pleasure and Pain in Aristotle's Ethics", The Blackwell Guide to Aristotle's Nicomachean Ethics, R. Kraut (ed.) (Blackwell Publishing 2006), pp. 272-273.
} 
perception, and this is felt as pleasurable. Although Aristotle doesn't use this pleasureactivity scheme in all his works, it seems to explain all the pleasurable experiences.

In Frede's opinion, it would have been better for Aristotle to distinguish between 'remedial pleasures' (that is, pleasures with a lack-replenishment structure, preceded by desire) and pleasures which are the result of unimpeded natural activities: "Given that he regards the pleasures of the body as the tempters to excess and antidotes to pain, it might seem a much better solution to assign to them the status of remedial pleasures as he does in he Rethoric and to distinguish them from the pleasures of unimpeded natural activities" ${ }^{\prime 2}$. However, this distinction, which could be useful, would involve the problem of how to understand the nature of pleasure. It could be said that from an objective point of view (from the outside) it is possible to speak of two kinds of pleasurable activities: those which are due to restoration to the natural state (there is a lack which is fulfilled), and those which are due to the performance of some natural disposition $(\dot{\varepsilon} \xi 1 \varsigma)$. But, in every case, there is a self-perception of perfection in which the pleasurable experience consists.

Some of the problems which Frede points out seem to disappear when it is noticed that pleasure accompanies the awareness of perfection of the natural state. Frede, just like Urmson, makes a distinction between two kinds of pleasures as if there wouldn't be a metaphysical connection between them. But this connection seems to exist, and is the awareness of perfection of our own nature which is present at the time we experience pleasure, because pleasure is just a quality of this self-awareness (the perfect $\dot{\varepsilon} v \varepsilon ́ p \gamma \varepsilon 1 \alpha$ ). As Urmson, Frede thinks that eating, drinking and sexual pleasures are sensuous feelings, and they cannot be understood as perfect activities ${ }^{33}$ and that the $\dot{\varepsilon} v \varepsilon$ p $\gamma \varepsilon 1 \alpha$ explanation of pleasure (what she calls the performative aspect) that Aristotle gives in the Nicomachean Ethics is unsatisfactory in the case of some pleasures: "We hear, see, touch, or taste many things in the most natural and therefore 'perfect' way without either pleasure or pain, as the examples of everyday activities of eating and drinking and

\footnotetext{
${ }^{32}$ Frede, Dorothea, "Nicomachean Ethics VII. 11-12: Pleasure", Aristotle: Nicomachean Ethics Book VII. Symposium Aristotelicum, C. Natali (ed.), (Oxford University Press 2009), p. 201.

${ }^{33}$ Cfr. Frede, Dorothea, "Pleasure and Pain in Aristotle's Ethics", p. 265.
} 
so on show; they are generally unimpeded, but often neither pleasant nor unpleasant. It would be quite a bad ad hoc explanation that neutral sense experiences lack pleasure

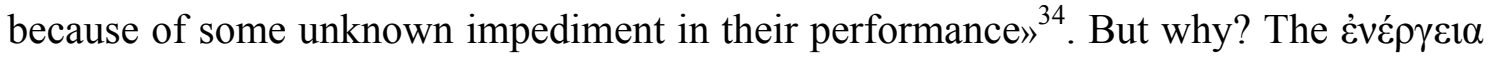
explanation fits properly in the case of these pleasures, because when we touch, see, hear, etc., and we do not find pleasure it is because the whole activity, in which the use

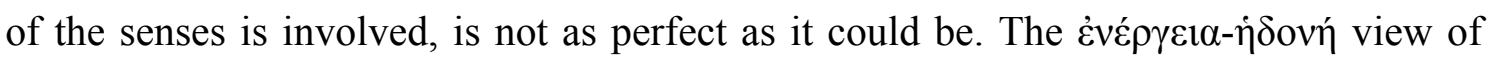
pleasure gives light to see that it is only in the self-awareness of my perfect natural activity that I find pleasure. These moments of perfection do not always happen in the everyday life, because perfection in the activity requires that the human being as a whole, in his soul and in his body, is in his best condition ${ }^{35}$. If I am going on excursion to the mountains and I have a headache, I will not find pleasure in the contemplation of the mountain, even if I perceive it properly. There is something that lacks, and the activity is not perfect.

Another problem treated by Frede is that Aristotle limits his pleasure conception to the completion of activities, but it seems that there are processes which can be enjoyable even when they don't find their own end, just as I can find pleasure when I am listening to a Beethoven's sonata, although I don't listen to it until its end. This objection can be very easily replied, because when we are enjoying a process which has not reached its end, it is because there is a perfect or complete activity in this process. For example, when I am listening to the sonata, my conscious activity in the use of the senses and the intelligence is reaching perfection in every time the sonata is being

\footnotetext{
${ }^{34}$ Frede, Dorothea, "Pleasure and Pain in Aristotle's Ethics", p. 265.

${ }^{35}$ Moreover, some of the examples which Frede brings up as problematic are not so clear as they may seem. She says: «Suffering an injury is unnatural, and it constitutes an impediment, but it clearly is not an unnatural impeded activity. The same is true of unpleasant tastes, sights, and touches. Physically painful experiences clearly are detrimental processes, not impeded or unnatural activities». (Frede, Dorothea, "Nicomachean Ethics VII. 11-12: Pleasure", p. 204). But these cases can also be seen as natural impeded activities (or unnatural activities). In the one hand, it is natural and good to have a healthy body, and that is a good activity of the organism, and when someone is injured, that is an obstacle to the good activity of the organism. On the other hand, in the case of an injury the awareness of the perfection of one's body (which is a natural activity) isn't fulfilled, and one feels pain. In the case of unpleasant tastes, sights or touches, they are due to the lack of harmony between the faculty of perception and that which it is perceived, so that the natural activity doesn't develop in the right way.
} 
played. We find pleasure while listening to the sonata not because the sonata has reached its end, but because our activity in the use of the senses is perfect while the sonata is being played. The interpretation of pleasure as the awareness of the perfection of the natural activities (nourishing, growing, seeing, hearing, contemplating, etc.) avoids some of the limitations that Dorothea Frede points out.

Aristotle's treatment of pleasure in the Nicomachean Ethics gives light to understand the human activity as a whole which imply the use of the senses and reason in the several activities we perform. In this way, there is a self-perception of our own existence in relation to what we do, see and think, and pleasure is related with the awareness of the vital capacities coming into perfection. Every sensation, every act of knowledge, is accompanied by pleasure or pain as something intrinsic to them. Pleasure

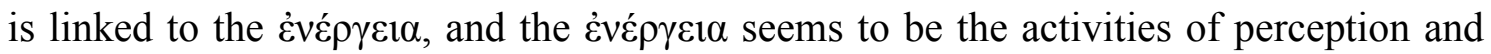
knowledge, that is to say, the conscious activities. It is in the self-perception, proper to these activities, that we may feel pleasure or pain, depending on the perfection of what is felt.

Manuel C. Ortiz de Landázuri

Universidad de Navarra

References

Bonitz, Hermann, Aristotelis Opera (vol. V). Index Aristotelicus, Walter de Gruyter 1961.

Bostock, David, "Pleasure and Activity in Aristotle's Ethics", Phronesis 331988.

Chung Hwang, "Different Meanings of the Term Energeia in the Philosophy of Aristotle", Philosophy and Phenomenological Research 171956.

Dirlmeier, Franz. Aristoteles: Nikomachische Ethik, Akademie Verlag 1999. 
Journal of Ancient Philosophy Vol. VI 2012 Issue 2

Festugière, André-Jean, Aristote. Le plaisir. Introduction, traduction et notes, Vrin 1946.

Forster, E. S. De Anima, Oxford 1963.

Frede, Dorothea, "Nicomachean Ethics VII. 11-12: Pleasure", Aristotle: Nicomachean Ethics Book VII. Symposium Aristotelicum, C. Natali (ed.), Oxford University Press 2009.

Frede, Dorothea, "Pleasure and Pain in Aristotle's Ethics", The Blackwell Guide to Aristotle's Nicomachean Ethics, R. Kraut (ed.), Blackwell Publishing 2006.

González, Francisco J., “Aristotle on Pleasure and Perfection”, Phronesis 361991.

Grant, Alexander, The Ethics of Aristotle, illustrated with essays and notes, Longmans 1874, 2 vols.

Joachim, Harold H., Aristotle. The Nicomachean Ethics, Greenwood Press 1985.

Kahn, Charles H., "Sensation and Consciousness in Aristotle's Psychology", Archiv für Geschichte der Philosophie 481966.

Owen, G. E. L. "Aristotelian Pleasures”, Logic, Science and Dialectic, M. Nussbaum (ed.), Cornell University Press 1986.

Ricken, Friedo, "Wert und Wesen der Lust", Aristoteles. Die Nikomachische Ethik, O. Höffe (ed.), Akademie Verlag 1995.

Ross, W. D. Nicomachean Ethics, Oxford 1915.

Taylor, C. C. W., "Urmson on Aristotle on Pleasure", Pleasure, Mind and Soul, Clarendon Press 2008.

Urmson, James O., “Aristotle on Pleasure”, Aristotle: a Collection of Critical Essays, J. M. E. Moravcsik (ed.) Macmillan 1968. 